\title{
The Correlation Among Language Learning Strategies, Learning Attitude and the Eighth Grade Students' Reading Achievement
}

\author{
Thesalonika ${ }^{1 *}$, Rusman Roni ${ }^{1}$, Mulyadi $^{1}$
}

\author{
${ }^{1}$ Universitas PGRI Palembang \\ *Corresponding Author Email: thesalonika2020@gmail
}

\begin{abstract}
The study is concerned the relationship between language learning methods, reading attitude, and the reading achievement of State Junior High School 3 PALI 8th grade students. The goal is to decide if there is a connection between language learning strategies, reading attitude, and reading achievement. This is a quantitative analysis that used a correlation research design. In this study, 30 students of the $8^{\text {th }}$ grade students of state junior high school 3 PALI in the academic year 2020/2021 were chosen as sample through cluster random sampling. The correlation analysis design was used in this study. Questionnaires were used to collect data, and the experiments were evaluated using the Product Moment Correlation Coefficient and Multiple Regression Analysis. The study's findings revealed a favorable relationship between language learning strategies and reading achievement, reading attitude and reading achievement, language learning strategies and reading attitude, and the final relationship between language learning strategies, reading attitude, and reading achievement.
\end{abstract}

Keywords: Language Learing Strategies, Reading Attitude, Reading Achievement

\section{INTRODUCTION}

Reading entails not only assigning words to written words or sounds to written words, but also comprehending the message or interpreting the written words. "Reading is the act of inferring meaning from documents. The terms "creating" and "meaning" are important here. There would be no reading if there is no sense being created"[1], [2] For some reason, students must learn to read. For starters, reading may aid in the development of a student's vocabulary. Second, reading will inspire them to improve their other skills including speaking, listening, and writing. Finally, reading will provide them with information.

Although teachers have though reading skill for the long time, the result is considered unsatisfactory because reading is very complex. The students get the same change to learn English in the classroom. But their achievement, particularly in reading is different from each other. There are many factors that affect students' reading. To some extent, the learners' weakness in reading may be caused by internal factors two of which are language learning strategies and reading attitude.

The reading attitude is very important to improve the rate of reading. In improving in the reading attitude, the reading attitude from very young children is stressed and the fact that reading should be emphasized starting from childhood. But in recent years the development of technology there has been a drop in children's reading attitude such cell phone, television, videos, computer games and other technological innovations that have the negative impact toward the rate of reading.[1]

mention some reasons causing the students' difficulty in comprehending reading material; for instance; students lack vocabulary, students are not interest in the topic of the reading material, students are not familiar with the grammar use in the reading material, students do not have good background of reading, and so on.

Students' language learning methods are acts they take to develop their own learning. Language learning techniques are particularly important because they offer opportunities for active, self-directed engagement, which is crucial for improving communicative competence. Students' language learning methods are steps they take to further their own learning. Language learners need strategies because they are a medium for successful, self-directed participation, which is critical for improving communicative competence [3] [5]. There are two types of learning strategies: direct and 
indirect. Both techniques may be used by students to develop their English skills., especially reading skills.

Learning techniques are often the deliberate thinking and action that a learner uses in order to achieve a learning objective. Strategic learners have a strong understanding of what a task entails, as well as the ability to orchestrate the methods that best suit both the task demand and their own learning strengths. [3]-[5]. Learning strategies are "intentional behavior and thinking that learners use to better understand, learn, or recall new information" throughout the learning process. These quotes demonstrate learning techniques such as focusing on a specific element of new knowledge, reviewing and organizing information during learning to improve understanding, and assessing learning after it is completed to determine whether additional action is required.[6]-[8]

In this research, the writer wanted to find out whether or not there is a significant contribution of language learning strategies and reading attitude toward the eighth grade students' reading achievement. The writer conducted the research at state Junior High School 3 PALI. Based on observation and interviews done by researcher to one of English teachers at the school. The researcher found some difficulties in learning reading to several reason. Firstly, many of students do not know to get idea for reading because they were confused how to make connect words into a sentence. Secondly, students don't know about reading attitude and about language learning strategies in learning.

\section{METHODS}

The research are conducted at the $8^{\text {th }}$ grade students of State Junior High School 3 PALI in the academic years 2020/2021. The school is located in Benakat Minyak, PALI district, South Sumatera Province. Data collected on June until July 2020. The research is quantitative research with correlation research design because there are correlation of $\mathrm{X}_{1}, \mathrm{X}_{2}$, and $\mathrm{Y}$. Quantitative research is a process of finding knowledge that uses data in the form of numbers as a tool to analyze information about what you want to know [9]-[13]

Population of research is the whole object of research [14]-[17]. The population of this study is the $8^{\text {th }}$ students of state junior high school 3 PALI. In this study, the writer used cluster random sampling technique where the subject are chosen in group or cluster not individually. In applying the cluster random sampling, the researcher was write the names of the eighth grade classes on small pieces of paper, roll them up and then takes one piece of paper randomly. There would be one class consisting 30 students taken as the sample of this research.
This study used two kinds of instruments in collecting the data, test and questionnaire. Moreover, in applying the questionnaire for language learning strategies and reading attitude, and a test to see how well you can learn. Before performing the research with the students, the writer was issued a test that consisted of a 30-item questionnaire for language learning strategies and a 25-item questionnaire for reading attitude. For reading achievement, the try out exam consists of 25 items in the form of multiple choice questions. This study is divided into three sections: the first discusses language learning methods, the second discusses reading attitudes, and the third discusses reading achievement.

\section{RESULTS AND DISCUSSION}

The correlation between variables can be seen from Table 1 . The data in the study were processed using the SPSS application to find the correlation between variables

Table 1. The Correlation between Language Learning Strategies and Reading Achievement

\begin{tabular}{|ll|l|l|}
\hline & $\mathrm{X} 1$ & $\mathrm{Y}$ \\
\hline $\mathrm{X} 1$ & Pearson Correlation & 1 & $.988^{* *}$ \\
& Sig. (2-tailed) & .000 \\
& $\mathrm{~N}$ & 30 & 30 \\
\hline $\mathrm{Y}$ & Pearson Correlation & $.988^{* *}$ & 1 \\
& Sig. (2-tailed) & .000 & \\
& $\mathrm{~N}$ & 30 & 30 \\
\hline
\end{tabular}

Table 1 shows that p-output is 0.000 . This result is lower than significance $\alpha 0.05$. It is significant. Therefore, $\mathrm{H}_{\mathrm{a}}$ is accepted while $\mathrm{H}_{\mathrm{o}}$ is rejected. Consequently, there was a correlation between language learning strategies and reading achievement.

Table 2. Correlation Between Reading Attitude and Reading Achievement

\begin{tabular}{|ll|l|l|}
\hline & X2 & Y \\
\hline X2 & Pearson Correlation & 1 & $.954^{* *}$ \\
& & .000 \\
Sig. (2-tailed) & 30 & 30 \\
N & $.954^{* *}$ & 1 \\
\hline Pearson Correlation & .000 & \\
Sig. (2-tailed) & 30 & 30 \\
N &
\end{tabular}

Table 2 shows that p-output is 0.000 . This result is lower than significance $\alpha 0.05$. It is significant. Therefore, $\mathrm{H}_{\mathrm{a}}$ is accepted while $\mathrm{H}_{\mathrm{o}}$ is rejected. 
Consequently, there was a correlation between reading attitude and reading achievement.

Table 3. The Correlation Between Language Learning Strategies and Reading Attitude

\begin{tabular}{|ll|l|l|}
\hline & & $\mathrm{X} 1$ & $\mathrm{X} 2$ \\
\hline $\mathrm{X} 1$ & Pearson Correlation & 1 & $.962^{* *}$ \\
& Sig. (2-tailed) & & .000 \\
& $\mathrm{~N}$ & 30 & 30 \\
\hline $\mathrm{X} 2$ & Pearson Correlation & $.962^{* *}$ & 1 \\
& Sig. (2-tailed) & .000 & \\
& $\mathrm{~N}$ & 30 & 30 \\
\hline
\end{tabular}

Table 3 Indicates that p-output is 0.000 . This result is lower than significance $\alpha 0.05$. It is significant. Therefore, $\mathrm{H}_{\mathrm{a}}$ is accepted while $\mathrm{H}_{\mathrm{o}}$ is rejected. Consequently, there was a correlation between language learning strategies and Reading attitude. (problem research no.3).

The result of the Contribution among Language learning strategies, reading attitude $\left(\mathrm{X}_{1}, \mathrm{X}_{2}\right)$ and reading achievement $(\mathrm{Y})$ is presented on table :

Table 4. The Correlation Among Language Learning Strategies, Reading Attitude and Reading Achievement

\begin{tabular}{|c|c|c|c|c|}
\hline & & $\mathrm{Y}$ & $\mathrm{X} 1$ & $\mathrm{X} 2$ \\
\hline $\mathrm{Y}$ & $\begin{array}{l}\text { Pearson } \\
\text { Correlation } \\
\text { Sig. (2-tailed) } \\
\mathrm{N} \\
\end{array}$ & 30 & $\begin{array}{l}.988^{\text {** }} \\
.000 \\
30 \\
\end{array}$ & $\begin{array}{l}.954^{* *} \\
.000 \\
30 \\
\end{array}$ \\
\hline $\mathrm{X} 1$ & $\begin{array}{l}\text { Pearson } \\
\text { Correlation } \\
\text { Sig. (2-tailed) } \\
\text { N }\end{array}$ & $\begin{array}{l}.988^{\text {** }} \\
.000 \\
30\end{array}$ & $\begin{array}{l}1 \\
30 \\
\end{array}$ & $\begin{array}{l}.962^{* *} \\
.000 \\
30\end{array}$ \\
\hline $\mathrm{X} 2$ & $\begin{array}{l}\text { Pearson } \\
\text { Correlation } \\
\text { Sig. (2-tailed) } \\
\text { N }\end{array}$ & $\begin{array}{l}.954^{* *} \\
.000 \\
30\end{array}$ & $\begin{array}{l}.962^{\text {** }} \\
.000 \\
30\end{array}$ & 30 \\
\hline
\end{tabular}

Table 4 Indicates that p-output of $\mathrm{X}_{1}$ and $\mathrm{Y}$ is Sig 0.000, $\mathrm{X}_{2}$ and $\mathrm{Y}$ is Sig 0.000 . This result is lower than significance $\alpha 0.05$. It is significant. Therefore, $\mathrm{H}_{\mathrm{a}}$ is accepted while $\mathrm{H}_{\mathrm{o}}$ is rejected. Consequently, there were a correlation among language learning strategies, reading attitude and the eighth grade students' reading achievement.

\section{CONCLUSION}

Language Learning strategies was significantly correlated with students' reading achievement Reading attitude was significantly correlated with students' reading. Language Learning strategies was significantly correlated with reading achievement. Language Learning Strategies and reading attitude were significantly correlated

\section{SUGGESTION}

English teachers should encourage the students in learning English and help them to build good reading attitude and find an appropriate learning strategies so they will be able to solve any problem or difficulty that they find in learning process. Additionally, the teachers should have good mastery of the material and best strategies in helping the students easier in reading achievement. $t \mathrm{t}$ is expected that students could be encouraged and motivated to apply language learning strategies, and reading attitude to improve their English especially in reading achievement. The students are expected to build up their strength and beliefs toward reading to increase their reading skills. The result of the study is expected to be beneficial reference for other related researchers. Some finding in this research can be used as reference in conducting further research about language learning strategies, reading attitude and reading achievement.

\section{REFERENCES}

[1] M. Freestone and J. M. O'Toole, "The impact of childhood reading on the development of environmental values," Environ. Educ. Res., vol. 22, no. 4, pp. 504-517, 2016, doi: 10.1080/13504622.2014.989962.

[2] F. Niklas and W. Schneider, "Home Literacy Environment and the beginning of reading and spelling," Contemp. Educ. Psychol., vol. 38, no. 1, pp. 40-50, 2013, doi: 10.1016/j.cedpsych.2012.10.001.

[3] N. Brooks, "Language and Language Learning, theory and practice," 1964.

[4] Y. Ardasheva and T. R. Tretter, "Strategy inventory for language learning-ELL student form: Testing for factorial validity," Mod. Lang. J., vol. 97, no. 2, pp. 474-489, 2013.

[5] M. Peacock and B. Ho, "Student language learning strategies across eight disciplines," Int. J. Appl. Linguist., vol. 13, no. 2, pp. 179-200, 2003.

[6] M. J. Prince and R. M. Felder, "Inductive teaching and learning methods: Definitions, 
comparisons, and research bases," J. Eng. Educ., vol. 95, no. 2, pp. 123-138, 2006.

[7] H. Retnawati, H. Djidu, Kartianom, E. Apino, and R. D. Anazifa, "Teachers' knowledge about higher-order thinking skills and its learning strategy," Probl. Educ. 21st Century, 2018, doi: 10.33225/pec/18.76.215.

[8] A. Kusumaningtias, S. Zubaidah, and S. E. Indriwati, "Pengaruh problem based learning dipadu strategi numbered heads together terhadap kemampuan metakognitif, berpikir kritis, dan kognitif biologi," J. Penelit. Kependidikan, vol. 23, no. 1, pp. 33-47, 2013.

[9] E. P. Ningsih and N. Hermita, "Pengaruh Ketinggian Tempat Terhadap Kandungan Proksimat Dan Komposisi Asam Oksalat Pada Kulit Umbi Talas Beneng (Xanthasoma undipes K.Kock) Yang Dibudidayakan," J. Agroekotek, vol. 8, no. June, pp. 139-142, 2016.

[10] R. G. T. Kusumah, A. Walid, S. Pitaloka, P. S. Dewi, and N. Agustriana, "Penerapan Metode Inquiry Untuk Meningkatkan Hasil Belajar Materi Penggolongan Hewan di Kelas IV SD Seluma," J. Pendidik. Mat. DAN IPA, vol. 11, no. $1, \quad$ pp. 142-153, 2020, doi: 10.26418/jpmipa.v11i1.34708.

[11] M. Taufiqurrahman, "Manajemen Sumber Daya Manusia Dalam Meningkatkan Mutu Pendidikan Di Pondok Pesantren Ar-Rahmah Curup, Kab. Rejang Lebong Bengkulu," At-Ta'lim Media Inf. Pendidik. Islam, vol. 18, no. 1, p. 203, Jun. 2019, doi: 10.29300/attalim.v18i1.1950.

[12] A. Saripudin and I. Y. Faujiah, "Strategi Edutainment dalam Pembelajaran di PAUD (Studi Kasus Pada TK di Kota Cirebon)," AWLADY J. Pendidik. Anak, vol. 4 (1), no. 1, pp. 129-149, Mar. 2018, doi: 10.24235/AWLADY.V4I1.2637.

[13] N. Shofiyah, "Penerapan Model Pembelajaran Modified Free Inquiry untuk Mereduksi Miskonsepsi Mahasiswa pada Materi Fluida," SEJ (Science Educ. Journal), vol. 1, no. 1, p. 19, 2017, doi: 10.21070/sej.v1i1.836.

[14] S. Alhunaini, K. Osman, and N. Abdurab, "The Development and Validation of Assessment Practices of Mathematical Thinking (APMT) Instrument," J. Pendidik. Malaysia, vol. 45, no. 02, pp. 79-91, 2020, doi: 10.17576/jpen-202045.02-08.

[15] N. N. Ariati, A. Fetria, A. A. P. Purnamawati, N. N. Suarni, I. A. E. Padmiari, and P. P. S. Sugiani, "Description of nutritional status and the incidence of stunting children in early childhood education programs in Bali-Indonesia," Bali
Med. J., vol. 7, no. 3, pp. 723-726, 2018, doi: 10.15562/bmj.v7i3.1219.

[16] B. Y. Hu, K. I. Vong, and M. Chi Kuan Mak, "An evaluation of China's Kindergarten quality rating system through the Chinese early childhood environment rating scale - the Zhejiang case," Early Years, vol. 35, no. 1, pp. 50-66, 2015, doi: 10.1080/09575146.2014.978266.

[17] A. Mauranen, "Hybridism, edutainment, and doubt: Science blogging finding its feet," NJES Nord. J. English Stud., vol. 12, no. 1, pp. 7-36, 2013. 